\title{
Take it on trust?
}

\section{Public trust in science is vital. But how do we ensure trust without imposing authority?}

In the preface ${ }^{1}$ to his 1923 play Saint Joan, George Bernard Shaw asserts, "In the Middle Ages people believed that the earth was flat, for which they had at least the evidence of their senses: we believe it to be round, not because as many as one per cent of us could give the physical reasons for so quaint a belief, but because modern science has convinced us that nothing that is obvious is true... But why the men who believe in electrons should regard themselves as less credulous than the men who believed in angels is not apparent to me."

In fact, few people in the Middle Ages believed that the Earth was flat, and there are still many who believe in angels. But the influence of scientific authority on public understanding, and its role in the formation of government policy, cannot be taken for granted.

Many of us would like to think that authority has little place in science. Within the confines of the scientific community and in the everyday practice of science this is largely true. The reason we physicists 'believe' in the existence of electrons is not because someone told us so, but because we understand the evidence, and in many cases have seen it first-hand. But for many of our colleagues in the wider scientific community (in the life sciences, say) this might not be true; and even less so for the general public.

So where does evidence stop and trust in authority begin? Televisions, computers and other technological wonders are proof enough to convince most people of the validity of the physical principles on which they are based. But what of global warming, evolution and other issues in which science and politics or beliefs collide? Whom is the public to believe?
This question is brought into sharp relief when the media, for reasons of balance, give equal time and equal weight to proponents of ideas at or beyond the fringe of mainstream science and to those who represent the scientific consensus. On issues such as evolution, for which there is scientific consensus, applying the crude journalistic balance inevitably distorts the public's appreciation. A simple solution is for news organizations to employ scientifically literate journalists who can judge, exercising a measure of authority, how to weight the arguments fairly.

But most scientific questions are not clear-cut. In a democracy, it is anathema to expect the non-scientific public to accept, on faith alone, the pronouncements of scientific experts, and most scientists wouldn't want them to. Yet the opposite response - of knee-jerk suspicion of the claims of science - is arguably worse. Dangerously low rates of childhood immunization, in even the most educated sectors of society, is one obvious example of the consequences of mistrust. Political inertia against action over climate change is another.

In Unscientific America: How Scientific Illiteracy Threatens Our Future ${ }^{2}$, Chris Mooney and Sheril Kirshenbaum reprise C. P. Snow's argument that integrating science into the very fabric of our democratic culture is vital. Education is an important element of this endeavour, but what should that entail? More and better teaching of science is not enough. It just isn't possible for people, scientists included, to reach the level of understanding needed to critically assess the implications and conclusions of every branch of scientific research.
From this month, high-school students in the UK will have the opportunity to take a course unit in anomalistic psychology, covering, among many topics, telepathy, psychokinesis, psychic healing, near-death experiences and talking to the dead. More than merely 'teaching the controversy', the aim of the course is to present the evidence and to explore the psychological origins of such exceptional human experiences.

Many will decry the inclusion of pseudoscience in the high-school curriculum - certainly if the comments beneath a recent commentary ${ }^{3}$ by Chris French, editor of The Skeptic magazine and head of the Anomalistic Psychology Research Unit at Goldsmiths College, University of London, are anything to go by. But to dismiss such ideas as having no place in a science education is to miss the point. Presenting fringe ideas as valid topics for study is not the same as asserting their factual validity. Rather it is a case-in-point of the sincere application of the scientific method to ideas beyond electrons, genes and climate systems.

Some level of trust in expert opinion is unavoidable, but a better awareness of the importance of science to politics, policy and collective prosperity, coupled with healthy, informed scepticism of the claims of scientists and non-scientists alike, is the only democratic antidote to the credulity that Shaw laments.

\footnotetext{
References

1. Shaw, G. B. Saint Joan (Penguin Books, 1946).

2. Mooney, C. \& Kirshenbaum, S. Unscientific America: How Scientific Illiteracy Threatens Our Future (Basic Books, 2009).

3. French, C. The Guardian <http://bit.ly/frenchcomment $>$ (2009).
}

\section{Don't overdo it}

\section{'Fun' science may grab summer headlines, but only the real thing has a lasting effect.}

The summer months are typically a 'silly season' for the media, when journalists look to lighter-weight, less-mainstream stories to fill their air time or column inches. Science also benefits from this opportunity to steal some headlines - although, as befits the season, those headlines may end up being slightly silly.
Last month, a group of Canadian scientists created a buzz with their publication, in Infectious Disease Modelling Research Progress (ISBN 978-1-60741-347-9), of an epidemiological study entitled 'When zombies attack!'. Although complicated by quarantine or treatment, the basic model for a population to be overrun by zombie hordes follows $\operatorname{det}(J-\lambda I)=-\lambda(-\beta \bar{Z}-\lambda)(-\zeta-\lambda)$, where $J$ is... well, that doesn't really matter. The conclusion is that a sequence of "quick, agressive attacks" would be the only means of saving our civilization.

It's entertaining, but now the silly season is behind us let's not overdo it with the fun stuff. Scientists have got far better stories to tell. 